\title{
Characteristics of mineral elements in shoots of three annual halophytes in a saline desert, Northern Xinjiang
}

\author{
Ke ZHANG ${ }^{1,2}$, ChunJian $\mathrm{LI}^{2}$, ZhongShao $\mathrm{LI}^{3}$, FuHai ZHANG ${ }^{3}$, ZhenYong ZHAO ${ }^{1}$, ChangYan TIAN ${ }^{1 *}$ \\ ${ }^{1}$ Key Laboratory of Oasis Ecology and Desert Environment, Xinjiang Institute of Ecology and Geography, Chinese Academy of \\ Sciences, Urumqi 830011, China; \\ ${ }^{2}$ College of Resources and Environmental Sciences, China Agricultural University, Beijing 100193, China; \\ ${ }^{3}$ Xinjiang Oilfield Water Supply Company, Karamay 834000, China
}

\begin{abstract}
Halophytes are valuable salt-, alkali- and drought-resistant germplasm resources. However, the characteristics of mineral elements in halophytes have not been investigated as intensively as those in crops. This study attempted to investigate the characteristics of mineral elements for annual halophytes during their growth period to reveal their possible physiological mechanisms of salt resistance. By using three native annual halophytes (Salsola subcrassa, Suaeda acuminate and Petrosimonia sibirica) distributed in the desert in Northern Xinjiang of China, the dynamic changes in the mineral element contents of annual halophytes were analyzed through field sampling and laboratory analyses. The results demonstrated that the annual halophytes were able to absorb water and mineral nutrients selectively. In the interaction between the annual halophytes and saline soil, the adaptability of the annual halophytes was manifested as the accumulation of $\mathrm{S}, \mathrm{Na}$ and $\mathrm{Cl}$ during the growth period and maintenance of water and salt balance in the plant, thus ensuring their selective absorption of $\mathrm{N}, \mathrm{P}, \mathrm{K}, \mathrm{Ca}, \mathrm{Mg}$ and other mineral nutrients according to their growth demand. By utilizing this property, halophyte planting and mowing (before the wilting and death periods) could bioremediate heavy saline-alkali soil.
\end{abstract}

Keywords: annual halophyte; mineral elements; desert; saline-alkali soil; Northern Xinjiang

Citation: Ke ZHANG, ChunJian LI, ZhongShao LI, FuHai ZHANG, ZhenYong ZHAO, ChangYan TIAN. 2013. Characteristics of mineral elements in shoots of three annual halophytes in a saline desert, Northern Xinjiang. Journal of Arid Land, 5(2): 244-254.

The saline land in Xinjiang accounts for about one third of all the saline land in China; approximately one third of the cultivated land in Xinjiang has undergone secondary salinization (Zhao and Li, 1999; Xi et al., 2006a). Vegetation coverage in saline deserts is very low, and increasing vegetation coverage can contribute greatly to reducing the greenhouse effect. However, the most promising aspects of increasing vegetation coverage are the change in soil fertility and the ecological improvement of the organisms' living environment.

In the soil-plant system interaction in saline deserts, the soil affects the characteristics of chemical elements in plants, which are closely related to the soil salt properties and react to soil fertility, for example, both Tamarix spp. and Haloxylon ammodendron Bge., under their canopies, show fertile island (or salt island) features (Xi et al., 2006b; Li et al., 2007; Yin et al., 2008a). Halophytes, grown in saline soil, have a higher soluble salt content $\left(\mathrm{Na}^{+}, \mathrm{Cl}^{-}\right)$(Flowers et al., 1977; Osmond et al., 1980; Ungar, 1991; Xia, 1994; Donovan et al., 1997; Yin et al., 2002; Zhang et al., 2007; Gao et al., 2010; Umethan et al., 2012). Previous studies were conducted on the characteristics of chemical elements in different halophytes in various habitats; they focused on the analysis of total salt, as well as $\mathrm{Cl}^{-}, \mathrm{Na}^{+}$and $\mathrm{SO}_{4}{ }^{2-}$ (Xia, 1994; Yin et al., 2002; Zhang et al., 2007; Gao et al., 2010), and the relation of salt and mineral nutrients (Marschner, 1995; Bai et al., 2008; Kudo and Fujiyama, 2010; Yuan et al., 2010).

*Corresponding author: ChangYan TIAN (E-mail: tianchy@ms.xjb.ac.cn) Received 2012-08-22; revised 2012-10-16; accepted 2012-11-02

(C) Xinjiang Institute of Ecology and Geography, Chinese Academy of Sciences, Science Press and Springer-Verlag Berlin Heidelberg 2013 
The contents of minerals in halophytes are not in proportion to those in saline soil, and the contents of some elements $(\mathrm{Cl}, \mathrm{Na})$ are far greater than those in glycophytes, which have different plant nutrition mechanisms with halophytes. However, there is little available literature on the macro and medium nutrient elements in halophytes, especially the dynamics of nutrient elements during the growth period, and their relationship with element concentrations in the soil. The growth properties of annual halophytes are similar to those of crops. Studies on plant nutrition regulation in saline soil using annual halophytes as the model plants (Flowers and Colmer, 2008) will provide an important basis for studying plant nutrition in saline agriculture.

\section{Study area}

The study area is located in the primary saline desert region of the National Field Observation and Experiment Station for Desert Ecology in Fukang, the Chinese Academy of Sciences. This area is to the northern side of Bogda Peak of Tianshan Mountains, and is an oasis/desert ecotone of the south Gurbantunggut Desert, belonging to the lower part of the Sangonghe alluvial plain. The area is located at $87^{\circ} 56^{\prime} \mathrm{E}$ and $44^{\circ} 17^{\prime} \mathrm{N}$, with an elevation of $475 \mathrm{~m}$, a typical temperate desert climate, an annual precipitation of $100-200 \mathrm{~mm}(70 \%-80 \%$ of which falling between May-September), and an annual evaporation of $1,000-2,000 \mathrm{~mm}$. Groundwater level in the study area is $2.9-5.3 \mathrm{~m}$ (changing with seasons) and has a salinity of approximately $2 \mathrm{~g} / \mathrm{L}$. Drought, high temperature, and strong light bring about seasonal surface-soil salt accumulation, leading to the generation of sulfate-dominant saline soil in which native succulent shrubs and herbs are sparsely scattered. This kind of habitat is commonly called a succulent halophytic desert. The total annual sunshine hours are $2,532.5 \mathrm{~h}$, and the frost-free period is $174 \mathrm{~d}(\mathrm{Xu}$ and Li, 2006; Xu et al., 2007).

\section{Materials and methods}

Three native annual halophytes distributed in the saline desert of Northern Xinjiang, i.e. Salsola sub- crassa, Suaeda acuminate and Petrosimonia sibirica, were chosen as the research subjects (Zhang et al., 2012). Samples were collected in the primary saline desert at Fukang station.

Sampling sites, which are $100 \mathrm{~m}^{2}$ in area, were randomly chosen in the primary saline desert where the three native halophytes were distributed. The sampling sites were flat, being far away from shrubs and under little human disturbance, so there were enough materials for sampling at different time points during the whole growth period. The halophyte shoots were obtained at different growth periods in 2009 and 2010, respectively. Halophyte shoots and soil in $0-100 \mathrm{~cm}$ soil profiles were sampled on different dates in 2009 and 2010 . Three $30 \mathrm{~cm} \times 30$ $\mathrm{cm}$ quadrats were randomly selected as 3 replicates, with a total of 9 quadrats for the three halophyte species; ditches of 100-cm depth were dug under plants in each quadrat; soil samples for each $10-\mathrm{cm}$ soil layer from bottom to top were collected for laboratory analysis. Plant counts were made for each quadrat: all plant shoots were cut and washed rapidly, air-dried, and freshly weighed, and then bake-dried at $105^{\circ} \mathrm{C}$ and weighed, crushed, and finally sieved for later use.

Determination of soil samples included: available $\mathrm{N}$, $\mathrm{P}$ and $\mathrm{K}$; water-soluble $\mathrm{Ca}, \mathrm{Mg}, \mathrm{Na}, \mathrm{Cl}$ and $\mathrm{S}$. Determination of plant samples included: total N, P, K, Ca and $\mathrm{Mg}$ in the shoots; water-soluble $\mathrm{Na}, \mathrm{Cl}$ and $\mathrm{S}$. Succulence was expressed as the ratio of water content in the shoots: (Fresh weight-Dry weight)/Fresh weight.

Available soil N, P and $\mathrm{K}$ were determined using the Distillation-Kelvin Digestion method, Olsen-P method, and Ammonium Acetate extraction method; water-soluble salts $\left(\mathrm{Ca}^{2+}, \mathrm{Mg}^{2+}, \mathrm{Na}^{+}, \mathrm{Cl}^{-}\right.$and $\left.\mathrm{SO}_{4}{ }^{2-}\right)$ were determined using conventional methods (1:5 soil/water ratio). After sampling solutions were obtained using the Sulfuric acid-Perchloric acid digestion Method, each element (N, P, K, Ca and $\mathrm{Mg}$ ) was measured as follows: $\mathrm{N}$ by Azotometer-Kelvin Digestion method, $\mathrm{P}$ by Mo-Sb-colorimetry, $\mathrm{K}, \mathrm{Na}, \mathrm{Ca}$ and $\mathrm{Mg}$ by Atomic Absorption Spectrometry (Bao, 2000). Plant water-soluble salts $\left(\mathrm{Na}^{+}, \mathrm{Cl}^{-}\right.$and $\left.\mathrm{SO}_{4}{ }^{2-}\right)$ were measured by conventional titration after boiling water extraction (Zhou et al., 2000). 
Data processing was performed using Excel 2003 and SAS 8.1 one-way ANOVA.

\section{Results}

\subsection{Soil properties of saline desert}

The analysis of the soil properties in 2009 and 2010 showed that soil water content, $\mathrm{pH}$ and bulk density increased from top to bottom. On the contrary, soil organic matter content was the highest in surface soil layer, and decreased from top to bottom. The electric conductivity of soil solutions of different layers in the two years differed only slightly, except for a relatively high value in surface soil layer in both years (Zhang et al., 2012).

\subsection{Changes of shoot water content during the growth period}

Shoot water contents changed only slightly in the three plant species during the growth period (Fig. 1). The variation ranges of average water content between different sampling periods in 2009 and 2010 were $830-870$ and $680-800 \mathrm{~g} / \mathrm{kg}$, respectively. Inter-annual variation was greater than the variation between different periods of each year. The data from both years demonstrated that, during the early growth period, the succulence of $S$. acuminate was the highest. With the

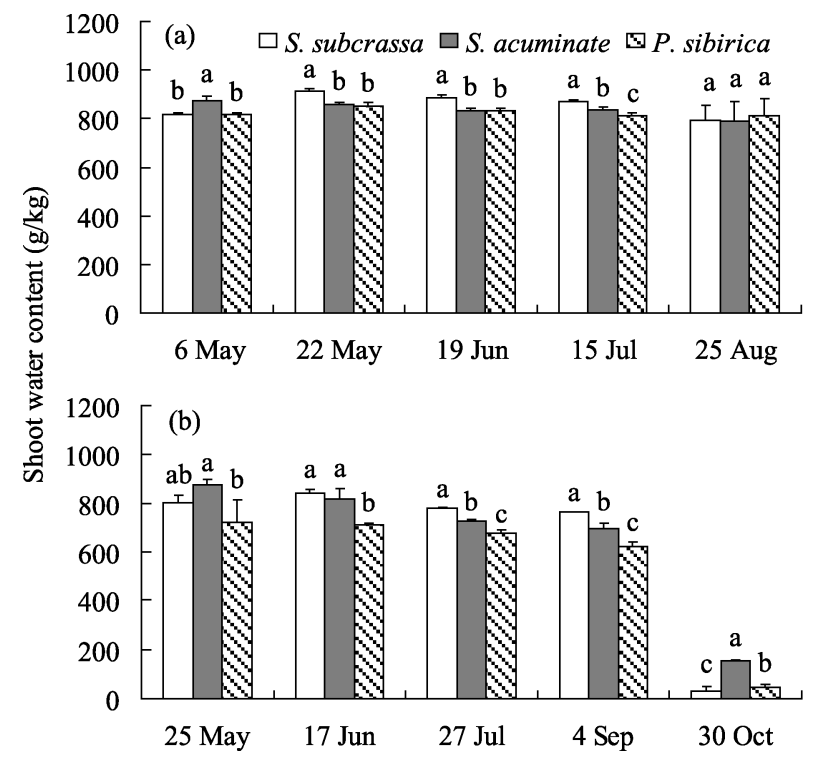

Fig. 1 Changes of shoot water content during the growth periods in 2009 (a) and 2010 (b). Different letters above columns for each sampling date represent significant difference among plant species $(P<0.05)$. Means \pm SE, $n=3$. extension of growth period, the succulence of $S . s u b$ crassa became the highest; the second and third highest were with $S$. acuminate and $P$. sibirica, respectively. At the last harvest in 2010, the three plant species withered, and the shoot water content was very low.

\subsection{Changes of $\mathrm{N}, \mathrm{P}, \mathrm{K}, \mathrm{Ca}$ and $\mathrm{Mg}$ concentrations in different soil layers during the growth pe- riod}

\subsubsection{Available soil N}

Data from both years showed that the change in available soil $\mathrm{N}$ (expressed as the mean for the 1-m soil profile), according to the time scale, was as follows: the available $\mathrm{N}$ began to increase in spring, reached its peak in June, and then decreased. The spatial distribution of the change in available $\mathrm{N}$ concentration was as follows: during the early growth period, it was relatively high in the middle and lower soil layers; during the middle and late growth periods, it was highest in the surface soil layer and evenly distributed below the surface soil layer, but fluctuated in the middle and lower soil layers during the different periods (Fig. 2).

3.3.2 Available soil $\mathrm{P}, \mathrm{K}$, water-soluble $\mathrm{Ca}$ and $\mathrm{Mg}$ The vertical distribution of available soil $\mathrm{P}, \mathrm{K}$, and water-soluble $\mathrm{Ca}$ gradually decreased from top to bottom, except that the available $\mathrm{P}$ decreased in the $0-40$ $\mathrm{cm}$ layer and was stable in the lower layers; water-soluble $\mathrm{Ca}$ demonstrated a transitional increase in the middle soil layer (Figs. 2, 3). The water-soluble $\mathrm{Mg}$ concentration in the soil gradually increased from the surface layer to lower layers, but gradually decreased in the $60-80 \mathrm{~cm}$ soil layer (Fig. 2). The temporal distribution characteristics of the above elements (according to the mean for the 1-m soil profile) were as follows: during the growth period, the available $\mathrm{P}$ concentration reached its peak from late May to early July in both years, suggesting that temperature and precipitation imposed certain influences on this period when the maximum available $\mathrm{P}$ concentration occurred. The available $\mathrm{K}$ concentration changed slightly in the growth season; it maintained a value of about $0.335 \mathrm{~g} / \mathrm{kg}$ in 2010 , and fluctuated within the range of $0.259-0.318 \mathrm{~g} / \mathrm{kg}$ in 2009 . Water-soluble Ca concentration increased during the early growth period, and then decreased to a minimum value in September, 

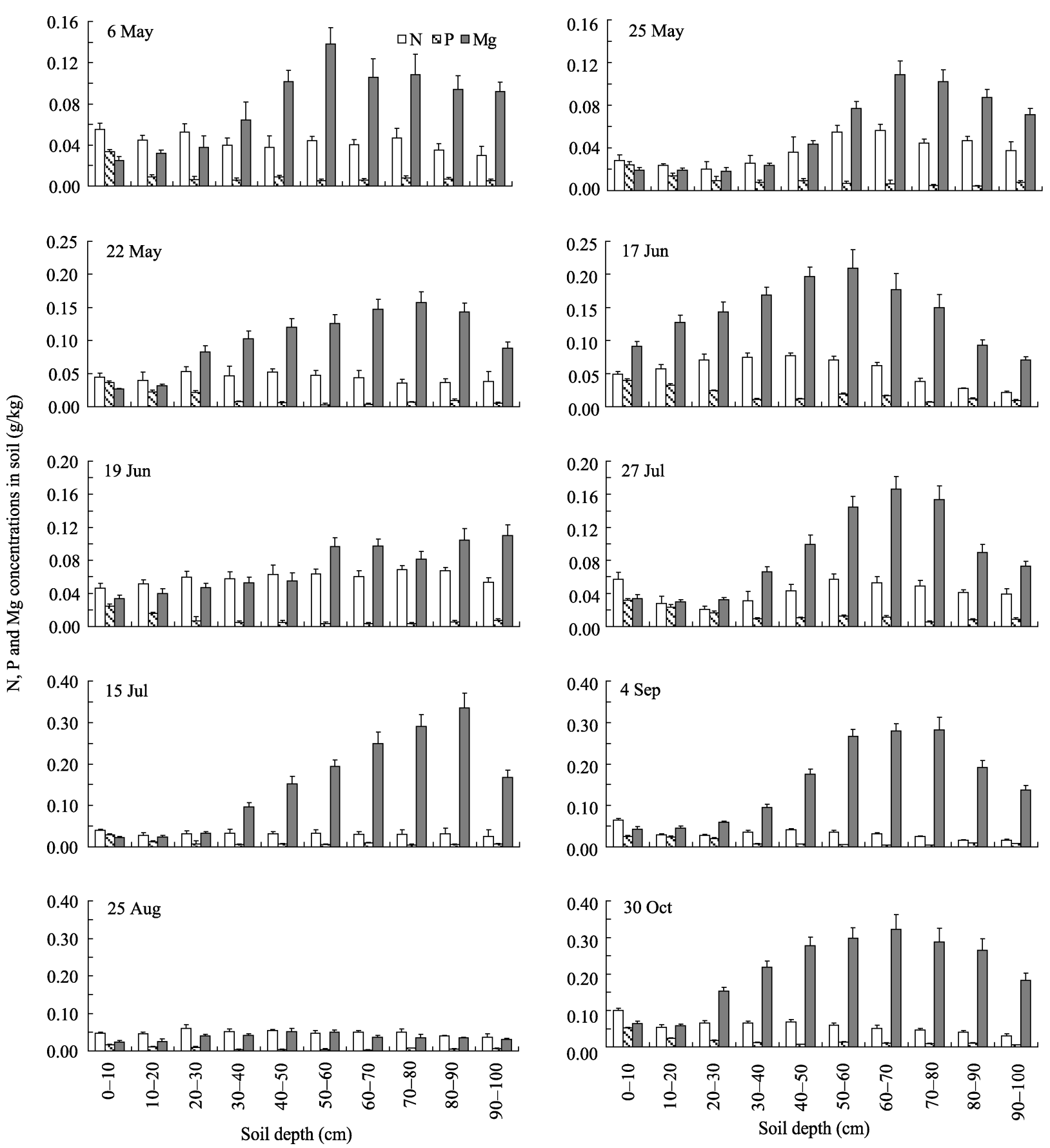

Fig. 2 Changes of available $\mathrm{N}, \mathrm{P}$ and water-soluble $\mathrm{Mg}$ concentrations in the $0-100 \mathrm{~cm}$ soil profile during the growth periods in 2009 (left column) and 2010 (right column)

and increased again in November. The water-soluble $\mathrm{Mg}$ concentration reached its peak in July 2009 and September 2010; the change curve of 2010 lagged one month behind that of 2009 .

\subsection{Changes of $\mathrm{Na}, \mathrm{Cl}$ and $\mathrm{S}$ concentrations in different soil layers during the growth period}

The characteristics of the spatial distribution of avail- able $\mathrm{Na}^{+}, \mathrm{Cl}^{-}$and $\mathrm{SO}_{4}{ }^{2-}$ in the soil (Figs. 3 and 4) were as follows: the distribution of $\mathrm{Na}^{+}$and $\mathrm{SO}_{4}{ }^{2-}$ in different soil layers in the two years was similar, developing from surface accumulation during the early period to vertically even distribution; the contents in each soil layer below the surface soil layer were similar, distributed evenly. $\mathrm{Cl}^{-}$gradually increased from the 

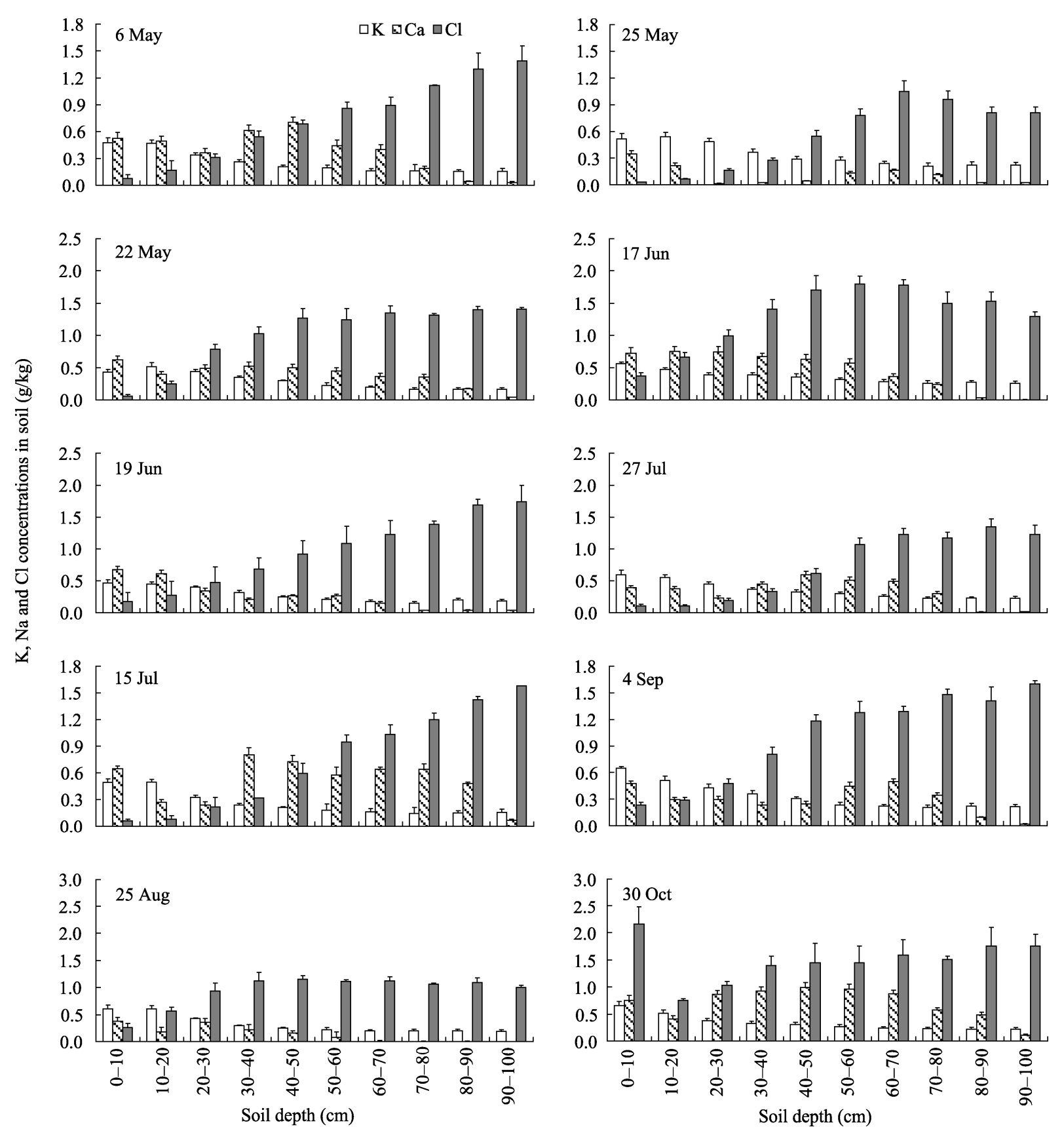

Fig. 3 Changes of available $\mathrm{K}$, water-soluble $\mathrm{Ca}$ and $\mathrm{Cl}$ concentrations in the $0-100 \mathrm{~cm}$ soil profile during the growth periods in 2009 (left column) and 2010 (right column)

surface layer to deeper layers. The temporal distribution characteristics were as follows: $\mathrm{Na}^{+}$and $\mathrm{SO}_{4}{ }^{2-}$ concentrations decreased slightly with the extension of growth period in 2009 , and on the contrary, they increased with the extension of growth period in 2010 . $\mathrm{Cl}^{-}$exhibited an increasing tendency with the extension of growth period in both years. The concentration of soil $\mathrm{SO}_{4}{ }^{2-}$ was the highest; the second highest concentrations were with $\mathrm{Na}^{+}$and $\mathrm{Cl}^{-}$. N and $\mathrm{P}$ concentrations were the lowest, suggesting that the main cations in saline soil were $\mathrm{Na}^{+}, \mathrm{Ca}^{2+}, \mathrm{Mg}^{2+}$ and $\mathrm{K}^{+}$, and the main anions were $\mathrm{SO}_{4}{ }^{2-}$ and $\mathrm{Cl}^{-}$.

\subsection{Changes of $\mathrm{N}, \mathrm{P}, \mathrm{K}, \mathrm{Ca}$ and $\mathrm{Mg}$ concentrations in the shoots}

$\mathrm{N}, \mathrm{P}$ and $\mathrm{K}$ concentrations in the shoots of the three annual halophytes showed the same characteristics: $\mathrm{N}$ concentration was the highest; the second highest was with $\mathrm{K}$; and $\mathrm{P}$ concentration was the lowest (Fig. 5). All of them gradually decreased with the advance of 
growth period, but the variation ranges were small. The order of N, P and K concentrations in the shoots was $S$. acuminate $>S$. subcrassa $>P$. sibirica.

A comparison of the $\mathrm{Ca}$ and $\mathrm{Mg}$ concentrations of the three halophytes during each sampling period in the two years indicated that the water-soluble $\mathrm{Ca}$
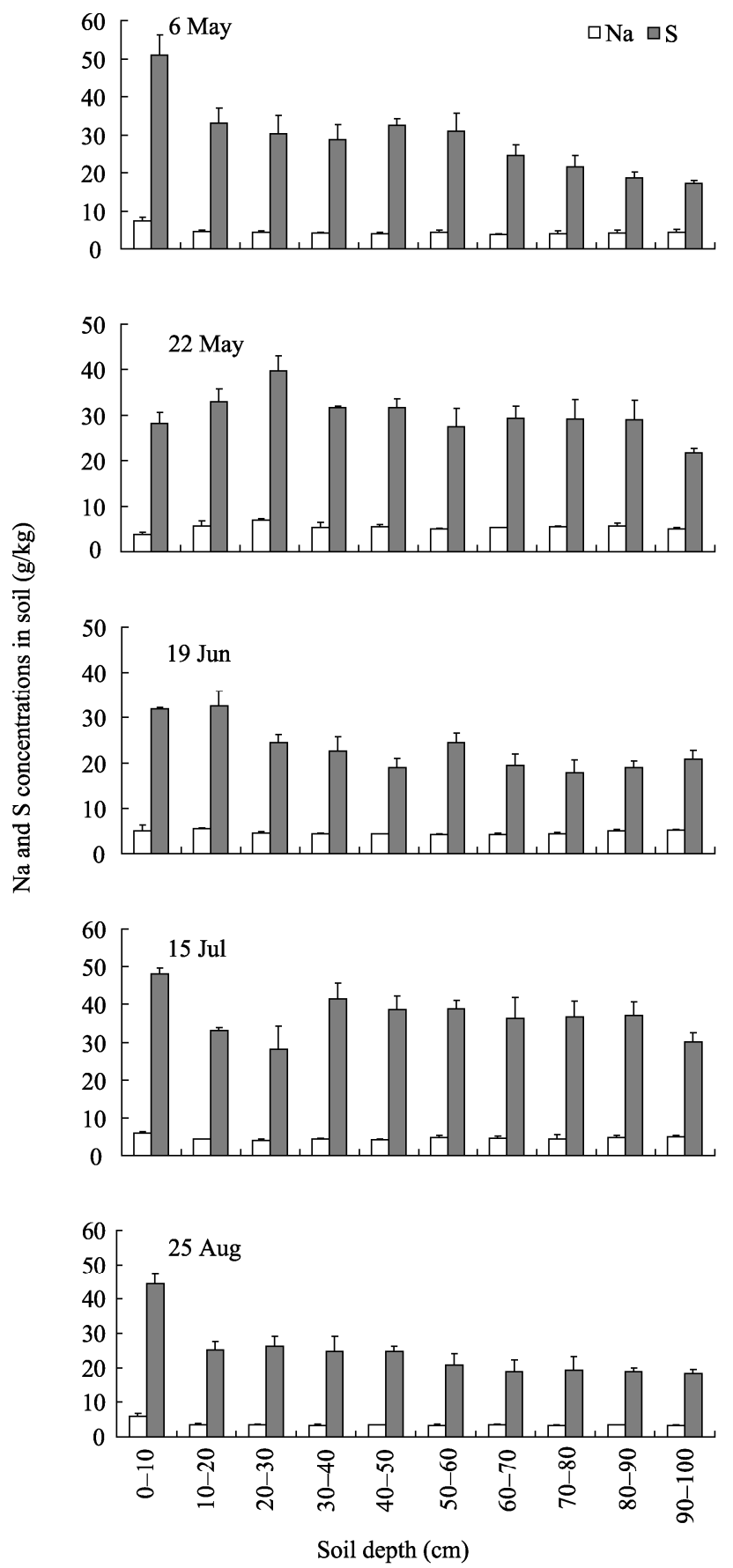

concentration was lower than the water-soluble $\mathrm{Mg}$ concentration in most cases. The order of the water-soluble Ca concentration was $P$. sibirica $>S$. acuminate $>S$. subcrass, and the order of the water-soluble $\mathrm{Mg}$ concentration was $P$. sibirica $>S$. subcrassa $>$ S. acuminate.
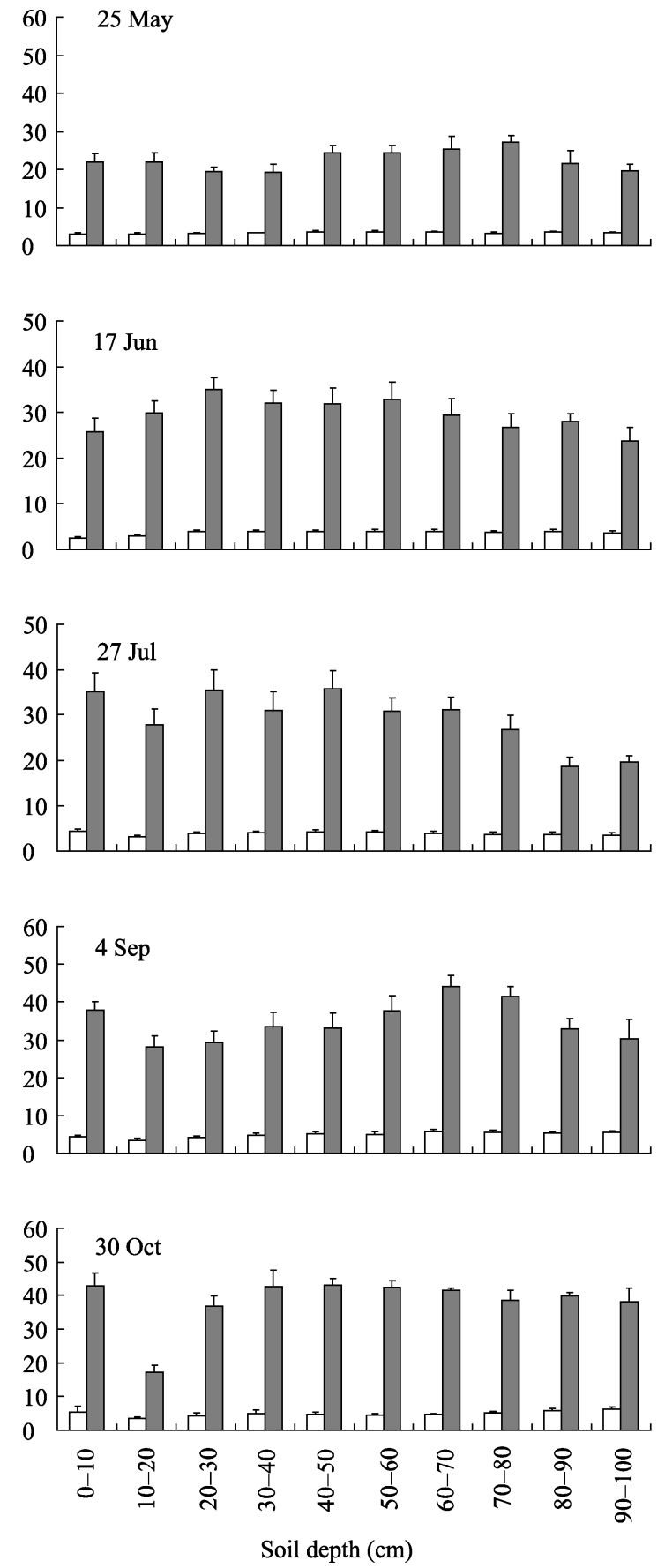

Fig. 4 Changes of water-soluble $\mathrm{Na}$ and $\mathrm{S}$ concentrations in the $0-100 \mathrm{~cm}$ soil profile during the growth period in 2009 
$\mathrm{N}, \mathrm{P}, \mathrm{K}, \mathrm{Ca}$ and $\mathrm{Mg}$ concentrations in the shoots $(\mathrm{g} / \mathrm{kg})$

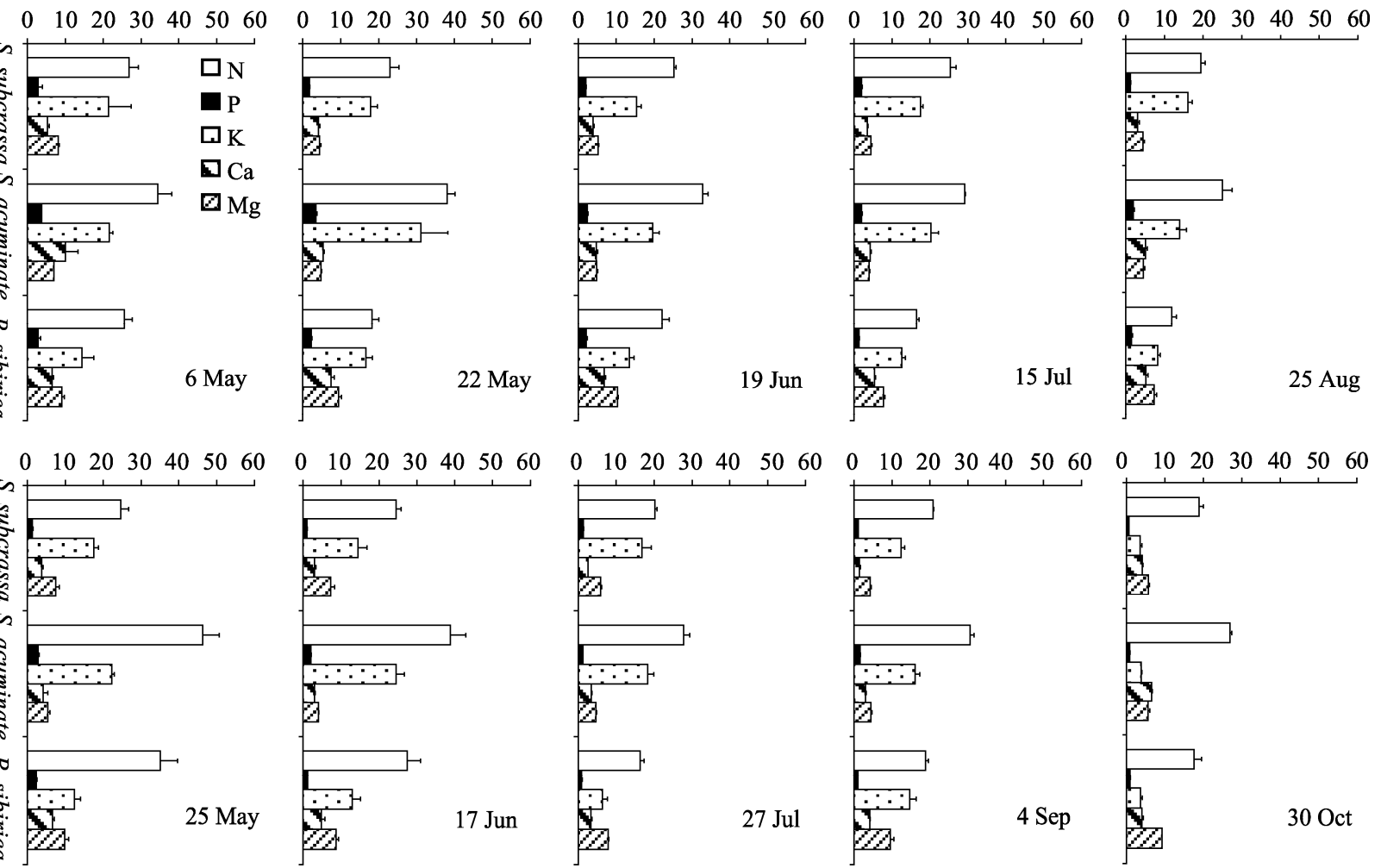

Fig. 5 Changes of N, P, K, Ca, Mg concentrations in the shoots of the three annual halophytes during the growth periods in 2009 (upper row) and 2010 (lower row)

\subsection{Changes of $\mathrm{Na}, \mathrm{Cl}$ and $\mathrm{S}$ concentrations in the shoots}

$\mathrm{Na}, \mathrm{Cl}$ and $\mathrm{S}$ concentrations in the shoots of the three annual halophytes showed the same characteristics: $\mathrm{S}$ concentration was the highest and $\mathrm{Cl}$ concentration was the lowest (Fig. 6). In 2009, Na concentration in the shoots showed a rapidly increasing tendency during the course of the growth period, and that of $S$. subcrassa increased most rapidly. In 2010, Na concentration increased during the early period, reaching its peak in June, and then decreased slightly, tending to be stable; Na concentration decreased significantly at the last harvest (death period). The order of $\mathrm{Na}$ concentration in the shoots of the three halophytes was $S$. subcrassa $>P$. sibirica $>S$. acuminate.

In 2009, the data for water-soluble $\mathrm{Cl}$ and $\mathrm{S}$ concentrations in the shoots were only obtained for $S$. subcrassa (Fig. 6). Data from both years showed that the water-soluble $\mathrm{Cl}$ concentration in the shoots of $S$. subcrassa displayed an increasing tendency with the extension of growth period, and maintained stable after reaching a certain level. $\mathrm{Cl}$ concentration in the shoots of the three plant species decreased to the minimum at the last harvest (death period). The order of $\mathrm{Cl}$ concentration in the three halophytes was $S$. acuminat $>$ S. subcrassa $>$ P. sibirica.

In 2009, the water-soluble $S$ in S. subcrassa increased continuously with the extension of growth period, but the case was not the same in 2010. Similar to those of $\mathrm{Na}$ and $\mathrm{Cl}, \mathrm{S}$ concentration in the three halophytes decreased significantly at the last harvest in 2010. The order of S concentration was S. subcrassa $>$ P. sibirica $>S$. acuminate. The ratios of $\mathrm{S}$, $\mathrm{Na}$ and $\mathrm{Cl}$ concentrations in the three halophytes were 5:2:1, 4:2:1 and 1:1:1 for S. subcrassa, P. sibirica and S. acuminate, respectively.

\section{Discussion}

\subsection{Characteristics of water content in the shoots of the three annual halophytes}

Water content is of special significance to annual halophytes. In the arid regions of Xinjiang, where 


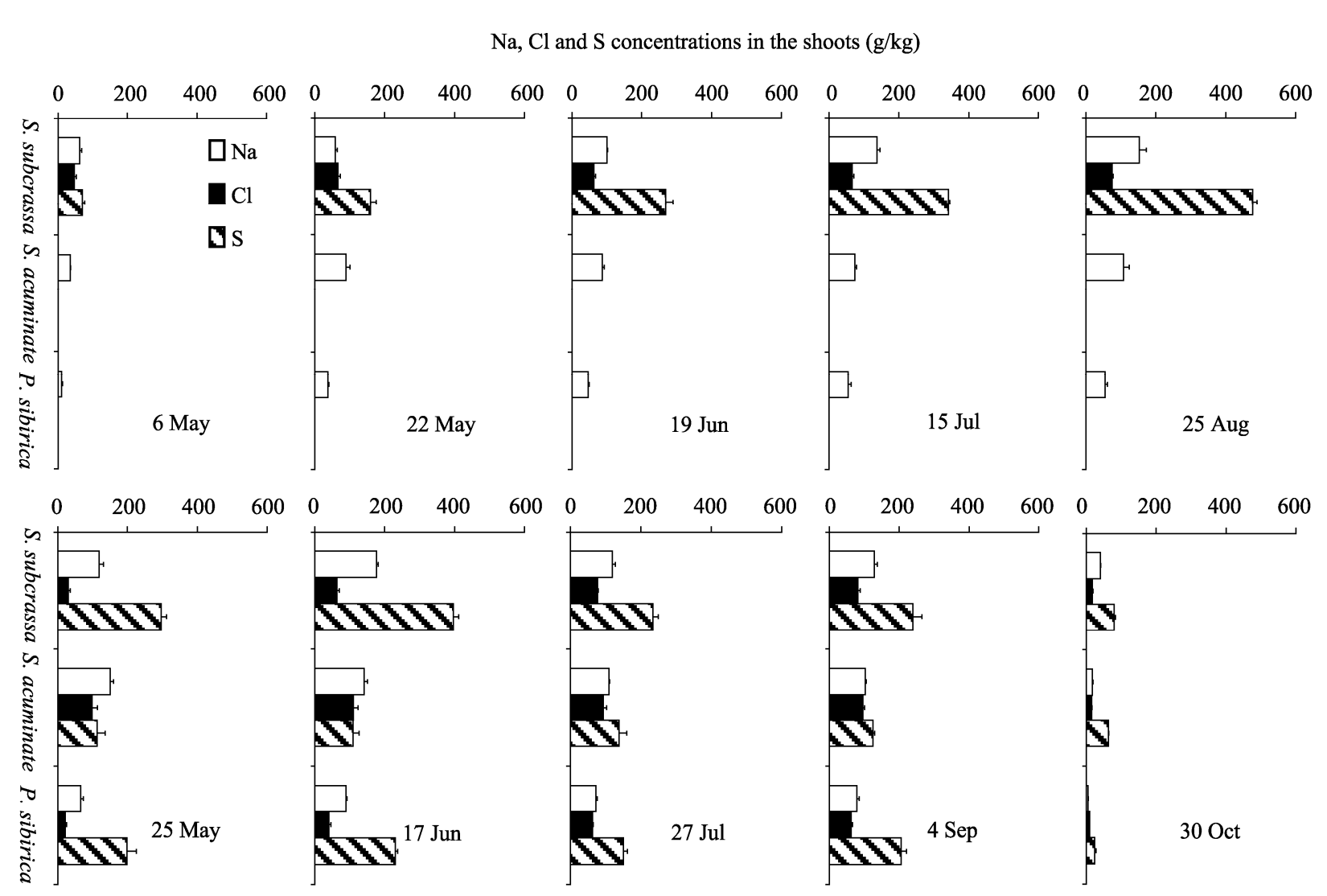

Fig. 6 Changes of water-soluble $\mathrm{Na}, \mathrm{Cl}$ and $\mathrm{S}$ concentrations in the shoots of the three annual halophytes during the growth periods in 2009 (upper row) and 2010 (lower row)

precipitation is rare and soil salinity is high, halophytes have developed a leaf/stem succulence structure similar to desert plants. Succulence reduces leaf surface area, which is beneficial for reducing evapotranspiration and damage from wind and sand; therefore it is clear that the higher the succulence, the stronger the stress resistance (Liu et al., 2006). Shoot water content was adopted to represent succulence in this study; it reflects not only succulence, but also plant water content. Comparison of the three annual halophytes revealed that the order of succulence was $S$. subcrassa $>S$. acuminate $>P$. sibirica. The differences in succulence also reflect different salt-drought resistant capacities to some extent. The water content of pasture plants is generally $590-800 \mathrm{~g} / \mathrm{kg}$ (Lai et al., 2008). It is only in the active parts of crops such as the stem shoots, tender stems and roots that the water content can reach above $800-900 \mathrm{~g} / \mathrm{kg}$. The water content in the shoots of the three annual halophytes was maintained at $800 \mathrm{~g} / \mathrm{kg}$ throughout the entire growth period. Huang (1988) demonstrated that suc- culent plants (tissue water content ranging from $750-800 \mathrm{~g} / \mathrm{kg}$ ) had a low evaporation ratio, while non-succulent plants (tissue water content ranging from 500 to $650 \mathrm{~g} / \mathrm{kg}$ ) had a high evaporation ratio. Therefore, maintaining relatively high water content during the entire growth period is one of the key strategies for the annual halophytes to adapt to extreme climatic and physiological drought.

\subsection{Characteristics of macro and medium element concentrations in the soil and shoots}

Soil in the desert of Northern Xinjiang was demonstrated to be chloride-sulfate saline soil, where the content of $\mathrm{SO}_{4}{ }^{2-}$ was about 28 times that of $\mathrm{Cl}^{-}$and the main composition of salt was $\mathrm{Na}_{2} \mathrm{SO}_{4}$ (Figs. 3 and 4). Cation concentrations in the soil were similar $\left(\mathrm{Ca}^{2+}\right.$ $>\mathrm{K}^{+}>\mathrm{Mg}^{2+}$ ), and they were $0.09,0.07$ and 0.03 times that of $\mathrm{Na}^{+}$, respectively. As macro mineral nutrients, although $\mathrm{N}$ and $\mathrm{P}$ were far lower than salt (Figs. 2 and 4), their contents reached mid-levels compared with the case in other soils, suggesting that the saline 
soil in the desert of Northern Xinjiang is not infertile and its productivity is affected by salinity rather than by nutrition. Due to the movement of groundwater (especially capillary water), concentrations of available soil $\mathrm{N}$ and water-soluble $\mathrm{Mg}$ gradually increased from the surface layer to lower layers, which is one of the features of saline soils in arid regions.

The concentrations of elements $\mathrm{S}, \mathrm{Na}$ and $\mathrm{Cl}$ were the highest in the three annual halophytes, and were similar to the order of the elements in the soil. Soil salinity affected the absorption of the three elements. $\mathrm{Na}, \mathrm{Cl}$ and $\mathrm{S}$ concentrations in crops were generally $0.01-80,0.01-80$ and $1.5-15 \mathrm{~g} / \mathrm{kg}$, respectively (Epstein and Bloom, 2005), while those in the annual halophytes reached $10-150,41-110$ and $70-477 \mathrm{~g} / \mathrm{kg}$, respectively. Thus, it is clear that $\mathrm{S}, \mathrm{Na}$ and $\mathrm{Cl}$ concentrations were the highest in the annual halophytes (much higher than the concentrations of other mineral elements), which was related to the highest concentrations of the three elements found in soil (Figs. 3-6). According to data for the period of strong growth (27 July), the order of salt content in the three annual halophytes was $S$. subcrassa $>S$. acuminate $>P$. sibirica. Generally, plants with higher salt content have greater salt tolerant capacities (Fig. 6). On the other hand, the high concentrations of $\mathrm{S}, \mathrm{Na}$ and $\mathrm{Cl}$ in the halophytes were clearly the basis for the plants' ability to obtain and sustain water in arid saline deserts; only by maintaining a low water potential with high salinity, could a series of physiological activities be carried out (Flowers et al., 1977; Gorham et al., 1980; Yeo, 1983). The concentrations of water-soluble $\mathrm{Na}, \mathrm{Cl}$ and S were very low in the plants on 30 October, 2010 (during the wilting and death period), suggesting that salt was not bound and could be discharged along with water loss. Since it was only during wilting and death period that salinity decreased significantly, it is possible that salt was discharged mainly through the leakage led by plasma membrane rupture. The salt was then distributed onto the surface of the plants with water and scattered in the surface soil with litter, leading to salt bioaccumulation in the surface soil layer. Our findings were supported by previous studies, which reported that, along with plant death, $\mathrm{Na}$ evaporated to the plant surface and scattered in the surface soil with litter, resulting in salt accumulation in this layer of the soil and the saline islands of halophytic shrubs such as Tamarix chinensis ( $\mathrm{Li}$ et al., 2007; Yin et al., 2008b).

The order of $\mathrm{N}, \mathrm{P}, \mathrm{K}, \mathrm{Ca}$ and $\mathrm{Mg}$ concentrations in the three annual halophytes was $\mathrm{N}>\mathrm{K}>\mathrm{Mg}>\mathrm{Ca}>$ $\mathrm{P}$, which was different from that in soil where the order was $\mathrm{Ca}>\mathrm{K}>\mathrm{Mg}>\mathrm{N}>$ P. Saline soil modified the nutrition characteristics of the three annual halophytes, and as a result, they not only accumulated a lot of salt, but also absorbed a large amount of $\mathrm{N}$ for plant growth. This situation not only ensured the demand for nutrition absorption, but also helped to maintain low water potential (Flowers et al., 1977; Gorham et al., 1980; Yeo, 1983; Kudo and Fujiyama, 2010). Mineral element concentrations in the annual halophytes growing in saline soil were passively affected by soil element contents and also actively influenced by the selective absorption of different elements. The ratio of selective absorption was expressed as the element concentration ratio of plant to soil.

Taking $\mathrm{Na}$ for example, element absorption ratio $(A R)$ could be expressed by the following equation:

$$
A R_{N a}=\text { Plant }_{N a} / \text { Soil }{ }_{N a}
$$

Plant $_{N a}$ is the concentration of $\mathrm{Na}$ in the plant, and Soil $_{N a}$ is the concentration of $\mathrm{Na}$ in the soil. Absorption ratio represents the elementary uptake of plant to soil. The absorption ratios of $\mathrm{N}, \mathrm{P}, \mathrm{Cl}, \mathrm{Mg}, \mathrm{K}, \mathrm{Na}, \mathrm{Ca}$ and $\mathrm{S}$ were calculated to be approximately 558,152 , $62,57,49,20,12$ and 7, respectively. It can be seen that the contents of $\mathrm{N}, \mathrm{P}, \mathrm{Mg}$ and $\mathrm{K}$ were significantly increased in the annual halophytes, but were much lower in the soil; however, the selective absorption ratios of macro elements $(\mathrm{Na}$ and $\mathrm{S})$ in the soil were relatively small, suggesting that the annual halophytes were able to control salt absorption. This selection mechanism requires further study.

\subsection{Ratios of different elements in the three annual halophytes}

Available $\mathrm{N}, \mathrm{P}$ and $\mathrm{K}$, water-soluble $\mathrm{Ca}, \mathrm{Mg}, \mathrm{Na}, \mathrm{Cl}$ and $\mathrm{S}$ in the soil can be regarded as the mineral components which are easily absorbed and utilized by plants. As can be seen from the ratios of different mineral elements in Table 1, the ratio of $\mathrm{N}$ in the annual halophytes was far higher than the ratio in soil and in crops as well. This suggests that halophytes have a high $\mathrm{N}$ absorption capacity. The ratios of $\mathrm{S}, \mathrm{Na}$ 
and $\mathrm{Cl}$ were the highest in saline soil and in the three annual halophytes as well, but their ratios were far lower in plants than in soil, demonstrating the plants' selectivity in salt absorption. The ratio of $\mathrm{Ca}$ in saline soil was high, while $\mathrm{Ca}$ accumulation was very low in the annual halophytes. This is related to the succulent structure of the three halophytes, which can decrease evaporation and reduce water loss.

In comparison of the three annual halophytes, there is little difference in the ratios of most nutritional elements, except for a relatively large difference in the ratios of $\mathrm{Na}, \mathrm{Cl}$ and $\mathrm{S}$. According to the results in Table 1, S. subcrassa and P. sibirica can be referred to as $\mathrm{Na}_{2} \mathrm{SO}_{4}$-type plant and $S$. acuminate can be referred to as NaCl-type plant. Different absorption of mineral elements may reflect interspecific differences.

Table 1 Comparison of the concentration ratios of different elements in halophyte shoots, saline soil and crops

\begin{tabular}{|c|c|}
\hline & Concentration ratio (N:P:K:Ca:Mg:Na:Cl:S) \\
\hline S. subcrassa & $16: 1: 11: 2: 4: 82: 41: 63$ \\
\hline S. acuminate & $15: 1: 9: 2: 2: 41: 37: 17$ \\
\hline P. sibirica & $13: 1: 7: 3: 5: 31: 24: 33$ \\
\hline $\begin{array}{l}\text { Mean for the three } \\
\text { annual halophytes }\end{array}$ & $15: 1: 9: 3: 4: 49: 34: 34$ \\
\hline Saline soil & $4: 1: 27: 34: 10: 381: 84: 783$ \\
\hline $\begin{array}{l}\text { Crops (Epstein } \\
\text { and Bloom, 2005) }\end{array}$ & $\begin{array}{l}(3-12): 1:(5-16):(0.7-12):(0.3-2):(0.007-16): \\
(0.007-16):(1-3)\end{array}$ \\
\hline
\end{tabular}

Note: in the soil, $\mathrm{N}, \mathrm{P}$ and $\mathrm{K}$ are available nutrients, and $\mathrm{Ca}, \mathrm{Mg}, \mathrm{Na}, \mathrm{Cl}$ and $\mathrm{S}$ are water-soluble elements; in the shoots, $\mathrm{N}, \mathrm{P}, \mathrm{K}, \mathrm{Ca}$ and $\mathrm{Mg}$ are total elements, and $\mathrm{Na}, \mathrm{Cl}$ and $\mathrm{S}$ are water-soluble elements. Data for the plants are the mean values of different sampling periods in 2009 and 2010; data for the soil are the mean values in the $1-\mathrm{m}$ soil profile of different sampling periods in both years. Concentration of $\mathrm{S}$ was converted from that of $\mathrm{SO}_{4}{ }^{2-}$ (S concentration $=\mathrm{SO}_{4}{ }^{2-}$ concentration $\times\left(\mathrm{S} / \mathrm{SO}_{4}\right)=\mathrm{SO}_{4}{ }^{2-}$ concentration $\times(32 /(32+16 \times 4))$.

\section{Conclusions}

Maintaining high water content during the entire growth period is one of the important strategies for the annual halophytes to adapt to extreme climatic and physiological drought.

$\mathrm{N}, \mathrm{P}, \mathrm{K}$ and $\mathrm{Ca}$ concentrations in the annual halophytes gradually declined with the advance of the growth period, then maintained within a certain range, and eventually decreased slightly during the wilting and death period (except for the Ca concentration, which significantly increased during the death period). The water-soluble Mg concentration maintained with- in a certain range throughout the entire growth period, with only slight changes. By using Mg nutrient absorbed in the vegetative period, the annual halophytes can maintain the dynamic fluidity of $\mathrm{Mg}$ during the whole growth period.

$\mathrm{Na}, \mathrm{S}$ and $\mathrm{Cl}$ concentrations were dominant elements in the annual halophytes, and were maintained at a high level during the growth period. Although the three annual halophytes accumulated a lot of salt during the growth period, salinity decreased significantly during the wilting and death period. By utilizing this property, planting halophytes and mowing them before the wilting and death period could effectively bioremediate heavy halomorphic soil.

It can be concluded from the ratios of $\mathrm{N}, \mathrm{K}, \mathrm{Na}, \mathrm{Cl}$ and $\mathrm{S}$ that, although the mineral element contents in the soil influence the distribution of mineral elements in the plants, the element composition in halophytes does not entirely depend on salt composition and quantity in the soil. This is due to their selective absorption properties and the differed adsorption of mineral elements among species.

\section{Acknowledgments}

This study was financially supported by the Scientific and Technological Project of Xinjiang Uygur Autonomous Region (201130106-2) and the Innovation and Sustainable Development Research on Forest Carbon Sink in Karamay. We would like to thank PiZhen HUANG, ChuanHua YIN, Lei WANG, Ping WANG, Li LI, LinXia WANG and MingFang HU for their advice and assistance. Thanks also go to Hui ZHANG and other laboratory staff.

\section{References}

Bai W B, Li P F, Li B G, et al. 2008. Some physiological responses of Chinese Iris to salt stress. Pedosphere, 18: 454-463.

Bao S D. 2000. Soil and Agricultural Chemistry Analysis. Beijing: China Agriculture Press, 49-56.

Donovan L A, Richards J H, Schaber E J. 1997. Nutrient relations of the halophytic shrub, Sarcobatus vermiculatus, along a soil salinity gradient. Plant and Soil, 190: 105-117.

Epstein E, Bloom A J. 2005. Mineral Nutrition of Plant: Principles and Perspectives ( $2^{\text {nd }}$ ed.). Sunderland: Sinauer Associates, Inc. Publishers, 325-412.

Flowers T J, Troke P F, Yeo A R. 1977. The mechanism of salt tolerance in halophytes. Annual Review of Plant Physiology, 28: 89-121. 
Flowers T J, Colmer T D. 2008. Salinity tolerance in halophytes. New Phytologist, 179: 945-963.

Gao R R, Zhao R H, Du X M, et al. 2010. Characteristics of root systems of two halophytes for adaptability to salinity. Scientia Silvae Sinicae, 46(7): 176-182.

Gorham J, Hughes L L, Wyn Jones R G. 1980. Chemical composition of the salt-marsh plants from Ynys Môn (Anglesey): the concept of physiotypes. Plant, Cell \& Environment, 3: 309-318.

Huang Z C. 1988. Study on ecology and physiology of desert plant. In: Research on Fluid Sand at Shapotou Area at the Southeastern Edge of Tengger Desert (2). Yinchuan: Ningxia People's Publishing House, 210- 244.

Kudo N, Fujiyama H. 2010. Responses of halophyte Salicornia bigelovii to different forms of nitrogen source. Pedosphere, 20: 311-317.

Lai Q, Li Q F, Morigen A, et al. 2008. Research on pasture water content determination and dry-fresh ratio evaluating method. Inner Mongolia Prataculture, 20(3): 4-7.

Li J, Zhao C Y, Zhu H, et al. 2007. Species effect of Tamarix spp. and Haloxylon ammodendron on shrub "fertile island". Acta Ecologica Sinica, 27(12): 5138-5147.

Liu Y, Ding T L, Wang B S. 2006. Study on the leaf succulence of Suaeda salsa under differently natural saline environments. Journal of Shandong Normal University (Natural Science), 21(2): 102-104.

Marschner H. 1995. Mineral Nutrition of Higher Plants. New York: Academic Press.

Osmond C B, Björkman O, Anderson D J. 1980. Physiological Processes in Plant Ecology: Toward a Synthesis with Atriplex. New York: Springer-Verlag, 486.

Umethan K, Halil K, Chen Q J, et al. 2012. Study on daily change and middy depression of Photosynthesis of Alhagi pseudoalhagi and Vigna radiata under salt stress. Arid Zone Research, 29(6): 1040-1045.

Ungar I A. 1991. Ecophysiology of Vascular Halophytes. Boca Raton: CRC Press, 209.

Xi J B, Zhang F S, Mao D R, et al. 2006a. Species diversity and distribution of halophytic vegetation in Xinjiang. Scientia Silvae Sinicae,
42(10): 6- 12.

Xi J B, Zhang F S, Tian C Y. 2006b. Halophytes in Xinjiang. Beijing: Science Press, 64-77.

Xia Y. 1994. Chemical composition characteristics of dominant plant species in the Taklimakan Desert. Journal of Desert Research, 14(2): 30-36.

Xu H, Li Y. 2006. Water-use strategy of three central Asian desert shrubs and their responses to rain pulse events. Plant and Soil, 285: 5-17.

Xu H, Li Y, Xu G Q, et al. 2007. Eco-physiological response and morphological adjustment of two Central Asian desert shrubs towards variation in summer precipitation. Plant, Cell \& Environment, 30: 399-409.

Yeo A R. 1983. Salinity resistance: physiologies and prices. Physiologia Plantarum, 58: 214-222.

Yin C H, Tian C Y, Zhang F S, et al. 2002. Comparison between the characteristics of the content of mineral elements in three species of halophytes in Xinjiang. Arid Zone Research, 19(4): 42-44.

Yin C H, Feng G, Tian C Y, et al. 2008a. Enrichment effects of soil organic matter and salinity under the Tamarisk shrubs in arid area. Chinese Journal of Eco-Agriculture, 16(1): 263-265.

Yin C H, Feng G, Tian C Y, et al. 2008b. Variations of the fertile island effects beneath Tamarisk in Northern Taklamakan Desert, northwestern China and its implication to desertification process. Journal of Beijing Forestry University, 30(1): 52-57.

Yuan J F, Feng G, Ma H Y, et al. 2010. Effect of nitrate on root development and nitrogen uptake of Suaeda physophora under $\mathrm{NaCl}$ salinity. Pedosphere, 20: 536-544.

Zhang K, Zhang D Y, Wang L, et al. 2007. Study on the ionic absorption and transport in Salicornia europaea L. growing in natural habitats in Xinjiang. Arid Zone Research, 24(4): 480-486.

Zhang K, Tian C Y, Li C J. 2012. Root growth and spatio-temporal distribution of three common annual halophytes in a saline desert, Northern Xinjiang. Journal of Arid Land, 4: 330-341.

Zhao K F, Li F Z. 1999. Halophytes in China. Beijing: Science Press, $42-74$.

Zhou B, Li H, Li X M. 2000. Comparison of analyses methods on salt contents of plant. Arid Zone Research, 17(3): 35-39. 